\title{
Agricultural Growth Corridors - Unlocking Rural Potential, Catalyzing Economic Development
}

\author{
Sean de Cleene $e^{1}$
}

African agriculture has, on the whole, been characterized by low yield levels. Yet, as a continent it has significantly untapped potential in terms of productivity and agricultural growth. Infrastructure constraints, the high risk in complex value chains, and a traditional lack of government prioritization of agriculture, have historically provided limited incentive for investment. Agriculture represents 65 percent of African full-time employment, and an estimated 85 percent of the population is directly dependent on the sector for its livelihood. Increased productivity has the potential to improve the livelihoods of the rural poor and to enhance food security.

By entering into transformative public-private partnerships, Yara International ASA has played a catalytic role in developing the agricultural growth corridor concept, the rationale of which is to leverage investment and demonstrate a sustainable growth mode. With good soil and climate conditions, backbone infrastructure, and targeted catalytic financing there is great potential to cascade investments along the agricultural value chain.

The combined effect, should both the Beira Agricultural Growth Corridor in Mozambique (BACG) and the Southern Agricultural Growth Corridor of Tanzania (SAGCOT) be realized to their full potential, is the lifting of more than three million rural poor out of poverty. Through the leveraging of potential investments of about $\$ 5.4$ billion, annual agricultural revenues could increase accordingly by $\$ 2.2$ billion.

Despite decades of neglect, African agriculture has the potential to reclaim its former position as the main mover of economic growth on the continent. Africa has failed to cope with population growth since the early 1960s; in many cases productivity rates were stagnant or even in decline. Agricultural GDP growth toward the end of the first decade of the new millennium rose to about four percent. This demonstrates that potential exists for much more substantial growth if the various sectors come together to accelerate productivity rates in a sustainable way and in line with increasingly transparent and improved market dynamics.

1 Vice President, Global Business Initiatives, Yara International ASA. 
"The underdeveloped agricultural sector presents one of the most serious structural limitations to growth," the Africa Progress Panel claims, pointing to "severe under-investment" having left crop yields virtually stagnant at a mere quarter of the global average. ${ }^{2}$

Africa has in recent years taken great strides to move agriculture back to the top of its political and developmental agenda. One notable, high-level policy initiative is the 2003 Comprehensive Africa Agricultural Development Program (CAADP) document; it outlines Africa's agriculture strategy, which includes a calling upon the private sector to help accelerate growth in the sector.

\section{Global Challenges}

Food security for a future world population of more than nine billion people is one of the main global challenges of our time. It will require food production to increase 70 percent by 2050 . The challenge appears even more daunting against the backdrop of climate change and resource scarcity. This production increase has to be achieved on virtually the same amount of farmland - and in many cases without additional fresh water resources - while also aiming to reduce overall carbon emissions per ton of crop.

Global growth also affects agriculture: The world population will grow to an estimated 9.1 billion by 2050, meaning more mouths to feed. Africa alone is set to double its population, to about two billion in the next forty years. Global economic growth results in a bigger middle class and higher purchasing power, driving the consumption of agricultural produce, including dietary changes. At the same time, the McKinsey Global Institute argues that this growth will create more consumer markets that are large enough to be attractive to multinational companies, drawing investments and technology transfers. "Africa's agriculture holds enormous potential for companies across the value chain," the McKinsey study states. $^{3}$

Climate change, bringing with it more erratic weather conditions, is expected to have a detrimental effect on agriculture in large regions, not least in food-insecure parts of the tropics. In particular, South Asia and Sub-Saharan Africa may face severe challenges, pinpointing the need to strengthen agricultural productivity and create more climate-robust agricultural systems on the continent. Whereas agriculture's quest for more land drives up carbon emissions, increased productivity may help to mitigate emissions by reducing pressure on existing forests. By facilitating a growth strategy in the two agricultural growth corridors, productivity by the acre is set to increase significantly. In addition, in the case of Tanzania, work is already

2 Africa Progress Panel, "Doing Good Business in Africa: How Business Can Support Development", 2010.

3 Ibid. 
underway to develop a Green Growth Agricultural Growth Corridor overlay strategy to ensure that a balanced and long-term sustainable approach to investment and growth can be established, while in Mozambique such a sustainability type approach is implicit within the catalytic funding models being adopted.

\section{African Agriculture}

Agriculture constitutes the core of the African economy. The sector accounts for about 65 percent of full-time employment and an estimated 85 percent of Africans depend upon the sector, which contributes nearly a third of GDP, and over half of total export earnings to the continent's economies.

\subsection{African Challenges}

African agriculture faces a number of simultaneous challenges. Not only is the need for investments in physical infrastructure immense, there is an alarming backlog in investments in human resources, including innovation, R\&D, training, education, and extension service delivery.

The most critical challenge is low productivity. Whereas per capita food production since 1960 has doubled in Asia, it has remained largely stagnant in Africa south of the Sahara. In contrast, population growth rates have been - and look set to remain - high.

Decades of negligence and underinvestment have also resulted in reduced soil quality. With the lowest mineral fertilizer application rate of any region, at about seven to eight kilograms per hectare (against a middle and low-income country average of about a 1-200), and together with a shortage of organic fertilizers, African soils have been constantly mined for minerals without adequate replacement. Large areas of land have become unproductive, and need to be replenished with nutrients in a managed and sustainable way. In light of global warming, the dry areas of Africa will become even dryer, adding another challenge: lack of fresh water and low rates of irrigation. Altogether this has contributed toward low yields, weak markets - and resulting low profitability across the sector as a whole. ${ }^{4}$

Another challenge is the fact that today African producers are generally not particularly competitive in global markets, though this is slowly changing. At the same time, they are generally competitive in domestic markets - and supplying domestic and, even more so, regional markets harbors a great potential in the short to medium term. "We don't even have to think about markets outside of the conti-

4 The IPCC anticipates that dry areas, including large parts of Africa, which already suffer from fresh water shortages, will receive less rainfall. 
nent," Peter Hartmann, Director General of the International Institute for Tropical Agriculture, told the 2007 African Green Revolution Conference. ${ }^{5}$

Traditionally, business has not invested in African agriculture because of a lack of confidence in the sector as a whole, seeing the complexity of existing agricultural value chains as being too risky. In addition, inadequate infrastructure and unclear regulations often represent formidable challenges, with regional markets being fragmented and as a result lacking in scale.

While stagnating yields and decreasing support government support to agriculture were the story of the last few decades of the 20th century, in the last few years we have seen a complete turnaround regarding the willingness of both local governments and the international community - as well as the private sector - to invest in agricultural development in Africa. Recently, a raft of private sector agriculture funds have been launched, which could potentially boost private sector investment in the sector. However this will only occur if a sufficient pipeline of new and sustainable investments is developed.

A critical ingredient in converting both public and private sector commitment into actual on-the-ground sustainable investments is the need for governments and businesses to work together to overcome some of the main challenges to successful agricultural growth. A key focus therefore needs to be the forging of partnerships between the public and private sectors to ensure African agriculture can be more profitable for smallholder, medium, and large farmers alike.

Agricultural growth corridors demonstrate the potential for such publicprivate partnerships and for investments to achieve transformative change. Not only are they public-private partnerships in a traditional sense, they are also a multi-sector commitment to action. Farmers need access not only to land seeds and fertilizers but also to transport, power, and water. Ports must be efficient to be able to import inputs, and roads must be built to reach the farmers. Smallholder farmers and agro-dealers need access to rural financing through innovative financing instruments that support agricultural development at different stages. "Ensuring agriculture is financed appropriately in Africa will require a long term view. New models of longer term patient capital are required such as those proposed by AgDevCo. Such models seek to provide risk capital to partially fund development of last mile infrastructure, irrigation and land preparation, at concessionary rates however with a corresponding transformation requirement that often involves integration of small holder farmers as a prerequisite for financial support. More such models are critically needed if we are to see agriculture development go to scale."

5 The African Green Revolution conferences were initiated by and co-hosted by Yara in Oslo in 2006-2008. Summaries from presentations and proceedings can be found at: www.agrforum.com/about. 


\subsection{Political Support}

The political support rendered agriculture in Brazil, China, Vietnam, Thailand and other countries now hailed as initial success stories, has largely been lacking in Africa until very recently. After decades of relative negligence by national governments, bilateral donors, and multilateral organizations as well as national governments alike, agriculture in the last decade has begun to climb back to the top of political, economic, and development agendas in Africa.

The establishment of the New Partnership for Africa's Development (NEPAD) was a political watershed in Africa. ${ }^{6}$ In 2003, NEPAD together with the African Union (AU) issued the key strategy platform for the development of African agriculture, the Comprehensive Africa Agriculture Development Program (CAADP). This is a strong manifestation of African governments' commitment to address issues of growth within the sector, promoting rural development and food security. In 2005, African heads of state adopted the Maputo Declaration, ${ }^{7}$ whereby African governments provided strong political support to CAADP. Member countries of the AU are committed, inter alia, to allocate at least ten percent of national budgetary resources to agriculture and rural development, with the aim to secure an annualized sectoral growth rate of six percent. Pillar two of the CAADP calls for the private sector to help accelerate growth in the agricultural sector, i.a. through fostering partnerships to promote infrastructure development related to agriculture. ${ }^{8}$

In addition to this, leadership and country ownership of the agricultural growth corridor approach, has been a determining factor, particularly in Tanzania where President Kikwete's active and personal engagement together with a range of in country champions has been instrumental in the early stage success of the approach.

\subsection{African Green Revolution}

In 2004 in Addis Ababa, the then Secretary General of the United Nations, Kofi Annan, challenged the world to create a genuine African Green Revolution. ${ }^{9}$ Participating in the Addis seminar, Yara ${ }^{10}$ decided to head the response to Annan's

6 The NEPAD was created as a framework for political and economic cooperation by the Organization of African Unity and the G8 countries in 2001.

7 Formally, the Declaration on Agriculture and Food Security in Africa.

8 The CAADP contains five pillars, areas of priority: expansion of land; improvement of rural infrastructures; the enhancement of food supplies; the development of agricultural research; the sustainable development of livestock.

9 Africa's Green Revolution: A Call to Action was a high-level seminar convened by Ethiopia and the UN Millennium Project in Addis Ababa, July 2004.

10 Yara International ASA is a leading global chemical company that supplies mineral fertilizers and converts energy and nitrogen from the air into essential products for industrial customers. 
challenge to the private sector. In conjunction with its centenary celebration in 2005, Yara launched its Africa program, subsequently hosting the Oslo series of African Green Revolution Conferences, initiating local partnerships, and launching the concept of agricultural growth corridors. This concept has now developed into two concrete corridors, one in Mozambique and one in Tanzania. ${ }^{11}$

For Yara, its support of the African Green Revolution is firmly in line with its permanent presence on the African continent since 1985, and is consistent with its core business, namely providing knowledge-based solutions and improving agricultural productivity. The Africa program is in congruence with Yara's global corporate citizen approach, facilitating a platform of shared value creation.

With the Oslo conferences, Yara established a focus on and venue for privatepublic partnerships in support of the African Green Revolution, bringing together key stakeholders from the public and private sector as well as representatives from civil society, notably academia and NGOs.

\subsection{African Potential}

The vast potential of African agriculture is undisputed. As one of the continent's underutilized assets, it harbors the potential not only to feed the continent's population, but also to become its engine of economic growth and social development. Still, as the late Nobel laureate and supporter of the African Green Revolution Norman E. Borlaug used to say: "You can't eat potential." It has to be tapped.

Land is a key issue. Theoretically, there is plenty of land available worldwide. But realistically, options are limited. In Africa, the potential expansion is more promising, in particular south of the Sahara and the Sahel, in the Guinea Savannah Zone, an area stretching across the continent from Guinea in the West toward Ethiopia in the East, and southward through Uganda to another belt across from Angola to Mozambique and Tanzania. ${ }^{12}$ This is an area of about 600 million hectares, of which about 400 million is considered suitable for agriculture - and less than ten percent of it is cropped today. According to the Competitive Commercial Agriculture for Africa (CCAA) study, this is "one of the largest underused agricultural land reserves in the world."13

The area is often likened to the Cerrado region of Brazil or the northeast region of Thailand, both of which are hailed as success stories of modern agriculture. Both regions started their agricultural transformation with limited perceived po-

11 By 2010-11, Yara had initiated or joined three such partnerships; the Ghana Grains Partnership, the Malawi Agricultural Partnership, and the Tanzania Agricultural Partnership.

12 This vast area is defined and described in the "Awakening Africa's Sleeping Giant" (2009) report, which looks into the prospects for commercial agriculture in this and adjoining areas.

13 Ibid., p. 2. 
tential and poor infrastructure. Yet, with dedicated political support, technology application, and financial investments, both regions have become productive and highly competitive in world markets. They started with low-value commodities, and moved into higher-value products. Interestingly, in view of Africa's physical and social conditions that involve significant numbers of smallholder farmers, whereas Brazil achieved its market successes by relying on large-scale mechanized methods, smallholders dominate the sector in Thailand and it will be in finding a sustainable balanced solution to commercial agriculture in Africa, that successfully integrates smallholder farmers, that Africa will transition to a major food producing region.

In his book The Plundered Planet, ${ }^{14}$ the influential development economist and Director of the Center for the Study of African Economies at Oxford University, Professor Paul Collier, points to Brazil as a model of how food can be massproduced at scale. Drawing on these experiences, he argues that this model of large, high-productivity farms could "readily be followed in areas where land is underused," citing Zambia as an example. This opinion is shared by the distinguished soil expert and Director of the Tropical Agriculture and the Rural Environment Program at the Earth Institute, Columbia University, Dr. Pedro A. Sánchez, who points to a belt across southern Africa, including Zambia as well as Mozambique and Tanzania, encompassing the area of the two agricultural growth corridors. ${ }^{15}$ He calls it Africa's own Cerrado. ${ }^{16}$

For Africa to realize its agricultural potential, lessons can be drawn both from Brazil and Thailand. This includes the improvement of agricultural technologies, and government investments in rail and roads, as well as research and development. There must also be public support to develop a dynamic private sector, including commercialization of smallholder farmers at scale. Country case studies carried out by the CCAA study suggest that the prospects for commercial agriculture success, including involvement of smallholder farmers, in countries such as Mozambique, Nigeria, and Zambia, are as good as or even better than in Brazil and Thailand at the time of their agricultural revolutions.

At the same time, Africa needs to tailor any lessons learned, not least including those of the original Green Revolution of Asia and Latin America. Africa's own diverse challenges and unique conditions need to be addressed in a way that

14 The 2010 The Plundered Planet is a follow-up on Collier's book The Bottom Billion (2007), which made him one of the most influential development economists, together with Jeffrey Sachs and his The End of Poverty (2005) and Common Wealth (2008) both contributing to framing the global discourse on poverty and population, climate and development.

15 Sánchez is a staunch supporter of the African Green Revolution and Yara's Africa program, a former member of the Yara Foundation board, and active participant of the AGR Conferences. He also served as a Co-Chair of the UN Millennium Project Task Force on Hunger, on which Yara as the only private sector actor was a member.

16 Intervention by Sánchez at the AGR Seminar, hosted by Yara in Oslo, September 2009. 
matches its political ambitions and growth demands with broader social and environmental sustainability concerns. This will mean potentially leapfrogging development steps observed in other countries to ensure the best results.

\section{Value Chains}

In Africa there has been increased attention to - and political support for - developing food value chains. Notably, the AU and the Economic Commission for Africa (ECA) devoted their joint, influential publication on African economic development, the Economic Report on Africa 2009, to value chains. ${ }^{17}$

Pointing to the dominant role of agriculture in African economies, one of the report's main conclusions is the need for "innovative programs for strengthening the linkages between agriculture and other sectors and for promoting agricultural value chains and markets and national and regional levels." African countries, the two key institutions argue, need to form strategic partnerships through regional value chains that enhance investment, trade, marketing, and food security. They add that, in particular, such value chains could promote public-private partnerships - nationally and regionally - to capture the economies of scale and complementarities of diverse resource endowments.

Partnerships are also seen as key to strengthening value chains. In his keynote speech to the African Green Revolution Forum (AGRF) ${ }^{18}$ in Accra in September $2010,{ }^{19}$ Kofi Annan, in his capacity as Chairman of the Alliance for a Green Revolution in Africa (AGRA), stressed that "African agriculture must take a quantum leap forward," and that financing - and access to finances for the smallholder farmer - is needed. This, Annan argued, "all amounts to change across the value chain," emphasizing that, "partnerships are crucial to success". Underlining the key role of Mr. Annan in the development of the African continent, he also chairs the Africa Progress Panel, ${ }^{20}$ which has devoted attention to how business can contribute to development. He argues that the agricultural value chain is key to the development of Africa, citing the agricultural growth corridor concept as a leading example. He argues that greater African participation across the value chain must

17 AU/ECA, "Developing African Agriculture Through Regional Value Chains", 2009.

18 The AGRF was the successor to the Oslo series of African Green Revolution conferences, 2006-2008, a private sector-led initiative drawing participants from key stakeholders under the theme "Investing in African Agriculture".

19 Kofi Annan, Africa's Green Revolution Forum: Initiating a Quantum Leap Forward, Accra, 2010.

20 The APP was originally formed as a group of eminent persons following up on the commitments made at and after the G8 summit at Gleneagles and the UNK Commission for Africa in 2007. 
be secured if sustained economic growth is to be achieved. ${ }^{21}$ Following up on its World Development Report 2008 on agriculture, the World Bank in its 2011 strategy document entitled Africa's Future emphasizes the role of agriculture, and that strategic implementation rests on leveraging partnerships, promoting catalytic mechanisms and supporting PPPs. ${ }^{22}$

Concerns have been raised about the possible exclusion of smallholders. Studies of value chains from several continents, including Africa, show that this does not need to be the case, and is not a general feature. ${ }^{23}$ Not only are smallholders included in value chains, they are increasingly a part of food retail markets, supplying supermarkets, directly or indirectly. With growing urbanization and affluence, this is a largely untapped potential in Africa. Within the context of the agricultural growth corridors in Africa, the role of smallholders has been given particular attention. Forging greater linkages between modern agribusinesses and smallholder farmers and their communities is considered one of the best ways of contributing to inclusive economic growth on the continent.

The report from the AU and the ECA points out that regional value chains and markets for strategic commodities would not only increase competitiveness of agriculture at the farm level, but also trigger the development of agro-processing and agribusiness ventures at the regional level. This is part of the approach of the agricultural growth corridors, which focus on the local level with an emphasis on smallholders - within a broader, national and regional, framework including a number of sectors, not least the financial.

\section{Growth Corridors}

At the time these recommendations were presented, the first African agricultural growth corridor was in the making through the formation of an international consortium in 2008, working to establish the Beira Agricultural Growth Corridor (BAGC), and discussions were underway to initiate the Southern Agricultural Growth Corridor of Tanzania (SAGCOT).

The AGC is an initiative that was initially conceived by Yara but subsequently developed in close cooperation with a number of partners, not least the government of Norway, AgDevCo and Prorustica, ${ }^{24}$ and with the strong support of both

21 Africa Progress Panel, "Doing Good Business in Africa: How Business Can Support Development", 2010.

22 World Bank, “Africa's Future and the World Bank's Support to It", (2011) is the bank's new strategy for supporting Africa's development.

23 Swinnen and Maertens, "Finance Through Food and Commodity Value Chains in a Globalized Economy", in this volume, 2013.

24 AgDevCo is a not-for-profit distribution agricultural development company investing "social venture capital" to create commercially viable agribusiness investments oppor- 
the Tanzanian and Mozambican governments, and bilateral partners as well as multilateral donors including NORAD, NORFUND, USAID, DFID, AGRA World Bank, and FAO.$^{25}$ Other institutions including TransFarms, Tanzanian Agricultural Partnership, and the NEPAD Business Foundation also played key roles. The concept was originally presented by Yara at the Business Call to Action meeting hosted by the United Kingdom and the UNDP in May 2008, and launched at the private sector forum of the UN General Assembly in September 2008. Since then the initiative has gone on to include not only critical government support with the individual heads of state in both countries personally championing the framework - but also with strong buy-in from a range of local and international companies and organizations. The initiative has been endorsed by African regional institutions and governments, and support has been rallied through the World Economic Forum (WEF) New Vision for Agriculture. The WEF wasused as a platform to launch the respective investment blueprints: for the BAGC at the Africa regional meeting in Dar es Salaam, May 2010; and for the SAGCOT at the annual meeting in Davos, January 2011.

The basic idea of the AGC is to catalyze the development of rural areas by fostering sustainable agricultural development through value chains with agricultural clusters along existing trunk infrastructure corridors, establishing transformative public-private partnerships and using catalytic financing to attract capital from domestic and international, public and private sources. Relating to the African rural reality, it emphasizes the critical involvement and inclusion of the smallholder sector. Building on the platform initiated at the African Green Revolution conferences, we picked public-private partnerships as the favored strategy to increase investments in the continent's agricultural sector in general, and the corridors in particular. The sector at large as well as the specific corridors calls for large-scale investments covering a range of elements and involving a great number of stakeholders, locally and in a regional perspective. The corridor model is a way of breaking an impasse and catalyzing large volumes of private investments, enabling rural regions to develop and local agriculture to become sustainable - and internationally competitive.

It also provides a framework for other development agendas. Already institutions such as the Alliance for a Green Revolution in Africa (AGRA) have focused much of their breadbasket strategy into these two areas in these countries, while the USAID Feed the Future has also agreed in Tanzania to focus much of its investment into the SAGCOT area to ensure that that the subsequent synergies can be maximized to demonstrate the return on investment potential underpinning the corridor approach.

tunities, i.a. by taking out front-end risks. Prorustica is a consultancy specializing in fostering growth in agricultural commodity markets through creating partnerships.

25 Among the first financial supporters of the development of BAGC and SAGCOT were the Norwegian Agency for Development Cooperation, the Norwegian Investment Fund for Developing Countries, the World Bank, USAID, DFID. 


\subsection{Corridor Clusters}

The corridors are drawing on existing physical infrastructure: roads and railways, electricity grids, telecommunications systems. Within the ARC concept, investments will be made bringing infrastructure to the more remote areas, including feeder roads, electricity lines, and bulk water supply, easing farmers' access to inputs and opening output markets, as well as providing crop storage facilities and processing options. Not least important, by harnessing efficiencies in value chains this will lead to smallholders gaining from lower cost of vital inputs and services, such as seeds and fertilizers, electricity and financing. However, the hubs will not only benefit farmers; they are designed to support surrounding communities within a radius of 25 kilometers of the farm hubs with improved roads, water and electricity, and to enhance local job opportunities and provide financial services, including micro-financing and -insurance.

The perceived gains are based on the potential of "competitiveness through clustering"; due to economies of scale, farmers and agribusinesses are most likely to be successful when they are located in proximity to each other and related service providers. Each cluster, ${ }^{26}$ containing a number of components (see Fig. 1)

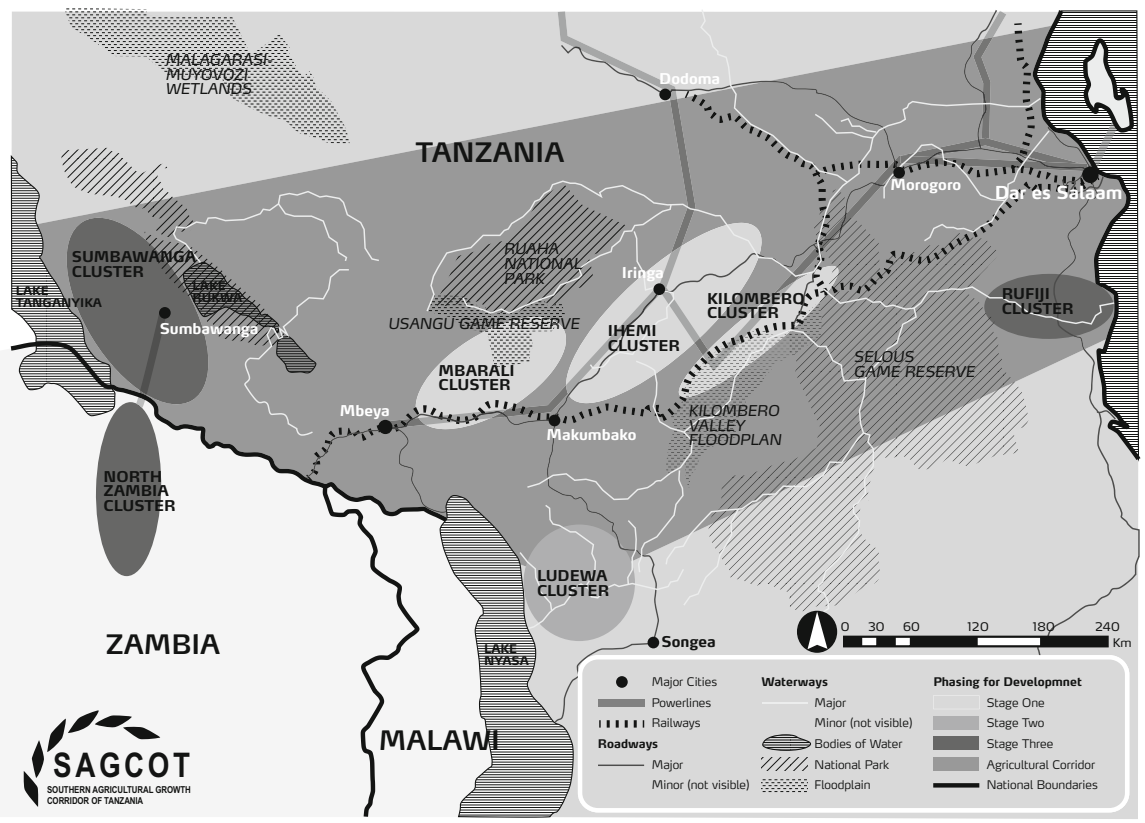

Fig. 1. SAGCOT - Southern Agricultural Growth Corridor of Tanzania

26 A cluster is defined as geographic concentrations of interconnected companies, specialised suppliers, service providers, and associated institutions. 
requires investments along the full agricultural value chain. A typical AGC cluster will include suppliers of farm inputs, machinery, and agriculture support services (extension agents, financial services), commercial farmers (large and small), processors and providers of infrastructure such as irrigation and roads. Clusters also include governmental and other institutions, such as universities, vocational training providers, and trade associations. Cluster development will be driven by the private sector, based on the actual needs and opportunities of the respective areas. Investments in sustainable, productive agriculture will be encouraged throughout the corridors.

Such clusters are considered vital for successful development, not only in Africa. In a 2011 article in the Harvard Business Review, Michael E. Porter and Mark R. Kramer write that: "Clusters are prominent in all successful and growing regional economies and play a crucial role in driving productivity, innovation, and competitiveness." 27 The authors cite the agricultural growth corridors as a leading innovation in the field of creating shared value. During 2009-10, Yara participated with other major companies in the development of the WEF roadmap document New Vision for Agriculture, ${ }^{28}$ unveiled in January 2011. Arguing that innovative tools can break bottlenecks in the value chain, and pointing to the BAGC as one example, the roadmap states that: "By coordinating their efforts, stakeholders can mitigate risk, leverage their contributions and build on each other's competencies to harness market forces for sustainable growth," calling for "coordinated investment in an infrastructure system to jumpstart and facilitate rural markets and reduce logistical inefficiencies."

The idea of clusters or hubs is not new, and there is considerable experience to draw upon, as well as support to harness. ${ }^{29}$ The World Bank, in its new Africa strategy (Africa's Future), points at the value of clusters, growth poles, and agglomeration externalities when opting to enable small-scale entrepreneurs in agriculture, manufacturing, and services to scale up in a time of rapid urbanization. Developing a new breed of operations, the Growth Poles Project," the bank is set to help African countries deploy a critical mass of reforms, infrastructure investments and skill-building, with a sub-set focused on key agribusiness industry. The

27 Porter and Kramer, "Creating Shared Value. How to reinvent capitalism - and unleash a wave of innovation and growth", (HBR, January-February 2011), citing Yara's involvement in forging clusters is an example cited as a "good example of a company working to improve framework conditions".

28 Defined as a roadmap for stakeholders, the New Vision for Agriculture is the outcome of a process in which 17 major companies working within the food sector participated, supported by McKinsey \& Company. Yara (incl. the author) participated in the Project Board and in the Working Group.

29 Among these is the case of Mali's mango export, boosted through developing a value chain including organizing, transportation, and quality control, enabling fruit from the land-locked country to be shipped out by sea, reducing transportation costs, increasing competitiveness. 
bank follows up on its 2008 Agriculture for Development report ${ }^{30}$ in the Agriculture Action Plan 2010-2012. ${ }^{31}$ Here, the bank points to the need to link farmers to markets and strengthen value chains through targeted investments in market places, rural roads, telecoms (market information) and electrification for agribusiness - and scaling up business models that better enable smallholder farmers to compete in growing higher-value markets. Facilitating agricultural entry and exit, and rural non-farm income, the bank will support regional clustering of economic activity.

\subsection{Corridors Established}

By 2011, two corridors had been established: the BAGC and the SAGCOT. The choice of initial corridors is based on two main factors: They were identified by the AU as potential regional breadbaskets having the conditions for strong economic development. They received dedicated support from the governments of Mozambique and Tanzania. Both projected corridors have large areas with high agricultural potential as well as a backbone of existing infrastructure.

\section{The BAGC}

The BAGC has all the natural conditions required for successful agriculture: good soils and climate, access to land and water resources. The major part of the corridor proper, Mozambique to Zimbabwe, contains a large area with huge agricultural potential. Of the ten million hectares of arable land available in the corridor area in Mozambique, only 1.5 million hectares are farmed; only 2 percent is farmed commercially, with less than 0.2 percent under irrigation; 98 percent is farmed by smallholders. About 190,000 hectares of land could be put under irrigation and produce world-class yields, with crops sold profitably in domestic, regional, and international markets. In Mozambique alone, at least 200,000 smallscale farmers are estimated to benefit directly from improved yields and increasing incomes as a result of the corridor; creating 350,000 new jobs and helping move up to one million people out of extreme poverty.

The BAGC is the gateway to south east Africa, linking inland areas of Zambia, Malawi, Zimbabwe, and Mozambique by road and rail networks to shipping facilities at Beira. During the time of apartheid South Africa in the 1980s, the Beira corridor was refurbished as an alternative trade route for Zimbabwe, until falling prey to the war in Mozambique and subsequent collapse of the economy in Zimbabwe. Much of the infrastructure has been repaired, and several major transportation projects are underway, including the Sena railway line to Tete and the port of Beira. The Machipanda rail line to Zimbabwe is operational.

30 Here, one of the points made, is that getting agriculture moving, "requires improving access to markets and developing modern market chains".

31 World Bank, "Agriculture Action Plan 2010-2012”, 2010. 
The BAGC blueprint calls for total investments of \$1.74 billion: An estimated $\$ 1.49$ billion from the private sector alongside public sector grants and loans of $\$ 0.25$ billion over a twenty year period.

\section{The SAGCOT}

The SAGCOT harbors a tremendous potential to increase the agricultural productivity in the region and farm output, especially in Tanzania. It could transform largely subsistence smallholder agriculture into a sustainable commercial farming sector, serving local, regional, and international markets. The Blueprint for Investment aims to bring more than 350,000 hectares into profitable, commercial production, tripling the area's agricultural output. It could lift two million people permanently out of poverty by creating at least 420,000 new employment opportunities within in the agricultural value chain - and bring Tanzania annual farming revenues of an estimated $\$ 1.2$ billion.

The SAGCOT benefits from existing infrastructure along the traditional trade route linking Tanzania to landlocked countries to the west, especially Zambia, Malawi, and the Congo. This route is also known as the Tazara Corridor, where the Tanzania-Zambia railway line (Tazara), originally built by China in the 1970s, links Dar es Salaam and the Zambian Copper Belt, and where the parallel Tanzania-Zambia highway (Tanzam) and the Tanesco electricity grid run. Building on Tanzania's Kilimo Kwanza (Agriculture First) strategy, the SAGCOT initially focuses on high-potential agricultural land, especially the areas on either side of the infrastructure backbone from Dar es Salaam through Morogoro to Mbeya. The corridor has a varied range of climates and altitudes, and diversity of soil qualities, which allows for a broad scope of crop production, including cereals, horticulture, coffee, tea, sugar, potatoes, banana, beans, vegetables, and sunflowers, as well as for beef, poultry, and dairy.

The SAGCOT blueprint calls for total investments of $\$ 3.4$ billion; $\$ 2.1$ billion from the private sector alongside public sector grants and loans of $\$ 1.3$ billion over a twenty year period.

\subsection{Capital Requirements}

To finance the corridors, several types of capital and investments are needed. This calls for a rethink by donors and governments as to how they have traditionally financed agriculture. Much more focus is needed on financing the private sector to assist in bridging the early stage development of a commercial model, with smallholders as a key component, to the point that such an investment is ready and can be employed by mainstream commercial investors. Catalytic financing that blends "social venture capital" and match grant financing is sought to support companies and organizations to undertake project development that can be brought to scale; "patient equity" is needed to finance the scalable irrigation infrastructure devel- 
opment to farm-gate, catalytic value addition, and post-harvest development; commercial debt and equity is required to invest in on-farm operations, value addition and services; public investments and grants are called on for public infrastructure and targeted support to smallholder farmers.

Aiming to harness total private sector investments to the tune of $\$ 3.59$ billion for the two corridors combined, a Catalytic Investment Fund (CIF) has been established for each of them: with initial commitments of \$15 million for BAGC, and pledged commitments of over $\$ 70$ million for SAGCOT from players including the World Bank and USAID, the government of Norway and the government of Tanzania itself. In late 2010, the first round of loans to several start-up agriculture businesses in the Beira corridor region was provided by AgDevCo and by the time of going to print 23 catalytic investments had been made under the fund.

However a critical component of the catalytic fund approach is that such financing will leverage in additional private sector investment. Conservative estimates in the case of SAGCOT are that initial catalytic funding and similar investment facilities to the tune of $\$ 100$ million will leverage an additional private sector financing of $\$ 500$ million.

To highlight this fact, the first infrastructure investment on the ground was made by Yara, when we launched our \$20 million investment into a new fertilizer terminal near the port of Dar es Salaam in January 2011, at the same time as the SAGCOT blueprint was launched. The investment, declared the CEO and President of Yara International ASA Jørgen Ole Haslestad, served to strengthen the company's long-term commitment to the development of Tanzania's agricultural sector. Interestingly, the terminal was a result of an initial invitation from Tanzania to come and help stabilize the fertilizer market. Since then we have developed a constructive dialogue with the government and President Jakaya Kikwete, a strong supporter of the SAGCOT. The fertilizer terminal, with a revolving storage capacity of 45,000 tons, is a crucial component in improving the input supply chain and bringing vital crop nutrition to the interior, through the corridor.

At the same time as easing the access to minerals and helping to stabilize the fertilizer market, the terminal contributes to improve the efficiency of the key regional port of Dar es Salaam. Port efficiency is crucial in international trade, the World Bank states, ${ }^{32}$ requiring both institutional and infrastructure investments. In eastern Africa, several countries are land-locked, dependent on the harbors of their neighbors. Not only has trade been complicated by political disputes, the quality of transportation services and the capacity of port handling have often been particularly weak, adding further to the high costs of long transportation routes.

32 World Bank, "World Development Report 2010: Reshaping Economic Geography", 2010 . 


\subsection{Agro-Industries}

The AU/ECA report points out that regional value chains and markets for strategic commodities would not only increase competitiveness of agriculture at farm level, but also trigger the development of agro-processing and agribusiness ventures at the regional level. This is also the approach of the AGCs, focusing on the local level, within a broader crosscutting - national and regional - framework.

A crucial part of the corridor concept is for an increase in related off-farm economic activities, not least local agro-processing creating jobs and adding value. A related focal area is improvement of storage capacity and the reduction of postharvest losses. Both interventions are part of the African Development Bank Group's Agricultural Sector Strategy 2010-2014, together with other infrastructural investments, including feeder and community access roads.

Interestingly, the regional economic community, the Common Market for Eastern and Southern Africa (COMESA), ${ }^{33}$ has developed an agro-processing sector strategy to capture the full value of production and create employment, reduce poverty levels and increase economic growth. In so doing, the community points to the fact that in developed countries, more than 98 percent of all primary agricultural products are sold to agro-processing facilities, while in the COMESA region, the percentage is only $30 .^{34}$ In 2010 , the community, together with the International Fertilizer Development Center, announced the formation of the COMESA Regional Agricultural Inputs Program, responding to rising food prices by increasing agricultural productivity through improved access to finance, fertilizer, and seeds. ${ }^{35}$

\subsection{Regional Integration}

Regional economic integration has been a favored strategy in Africa since the foundation of the OAU in 1963, after most African countries had gained their independence. Still, this is a main ambition, and the agricultural growth corridors contribute to it - and as regional interconnections are key enablers of trade and integration.

The potential for regional trade in Africa is huge, concludes the International Assessment of Agricultural Knowledge, Science and Technology for Development in its study Agriculture at a Crossroads, ${ }^{36}$ noting that, "Intraregional trade development in agriculture, formalizing existing informal trade, value addition

33 COMESA, set up in 1993, comprises 19 member states with a combined population of over 430 million.

34 According to a report by the Technical Center for Agricultural and Rural Cooperation ACP-EU, 16 March 2010.

35 Press Release by the IFDC, 7 December 2010.

36 IAASTD, "Agriculture at a Crossroads", 2009. 
and ICT are all largely unexploited trade opportunities." Furthermore, the study argues, "It will be difficult for sub-Saharan Africa to participate more profitably in global trade without establishing a regional presence and national and regional infrastructure for value addition for local producers."

The need for regional integration was reaffirmed as essential for growth and development in Africa by the high-level Joining up Africa Conference in London in $2010,{ }^{37}$ where improved transport corridors enabling better trade and facilitating business development fostering integration was one issue on the agenda. Ensuring that the private sector is more effectively engaged in supporting regional integration, several barriers need to be addressed, the outcome statement notes. It also underlined the promotion of competitiveness and improving investment climates, as well as, "Continued innovation of financial and insurance products to support private investment in Africa, including enhanced guarantees, risk sharing mechanisms and enclave lending."

Today, African countries, on average, trade just about ten percent of their goods with each other, compared to 65 percent of goods traded between European countries.

\section{Infrastructure Backbone}

The agricultural growth corridors lie on existing infrastructure backbones, which have to be enhanced and extended. Infrastructure is a main prerequisite for economic development, and for agriculture. A number of studies support this analysis. Pointedly, the subtitle of a joint report of the Agence Française de Développement and the World Bank on Africa infrastructure reads: "A Time for Transformation." 38 The report says that the infrastructure networks "increasingly lag behind" those of other developing countries, with power generation representing the largest challenge. Although infrastructural shortcomings represent a major business constraint, depressing productivity, they have been responsible for more than half of Africa's recent improved growth performance, demonstrating the potential for further contribution. According to the Infrastructure Consortium for Africa (ICA) ${ }^{39}$ inadequate infrastructure is holding back Africa's economic growth per capita by two percent each year, and reducing firms' productivity by as much as

37 With high-level participation from key multilateral agencies such as the World Bank, the African Development Bank, and the Economic Commission for Africa, private companies, including Yara (represented by the author) was present at the conference, which aimed to bolster support and promote joined-up action for regional economic integration in Sub-Saharan Africa.

38 World Bank, “Africa's Infrastructure. A Time for Transformation”, 2009.

39 The ICA was launched at the G8 Gleneagles Summit in 2005, made up of bilateral donors and multilateral agencies, working to scale up investments in African infrastructure, from public, private and public-private sources. 
40 percent. "In order for Africa to become competitive, or realize its productive potential," the ICA states, "massive improvements in infrastructure is needed." 40 Adding to the challenge - and the costs - is the fact that Africa is the continent with the greatest number of landlocked countries.

The high cost of transport services represents a major constraining factor for agricultural productivity and profitability. Often at twice the cost of other regions, it increases production and transaction costs making vital inputs such as seeds and fertilizers prohibitively expensive and outputs uncompetitive on the international market. Africa's infrastructure deficit is described by the Center for Stratetgic \& International Studies (CSIS) as such: "Physical access to markets is far more restricted among farmers in Africa than among farmers in other regions of the developing rural world. Only a quarter of African farmers are within two hours of markets by motorized transport as compared to nearly half of farmers in Asia and the Pacific and 43 percent for the developing rural world." CSIS also notes that the intensification of African agriculture depends "in a very crucial way" on developing markets and related institutions. In the absence of functioning markets, the center states "rural areas remain trapped in subsistence-oriented economies in which neither the agricultural production sector nor the wider rural economy can grow." ${ }^{41}$

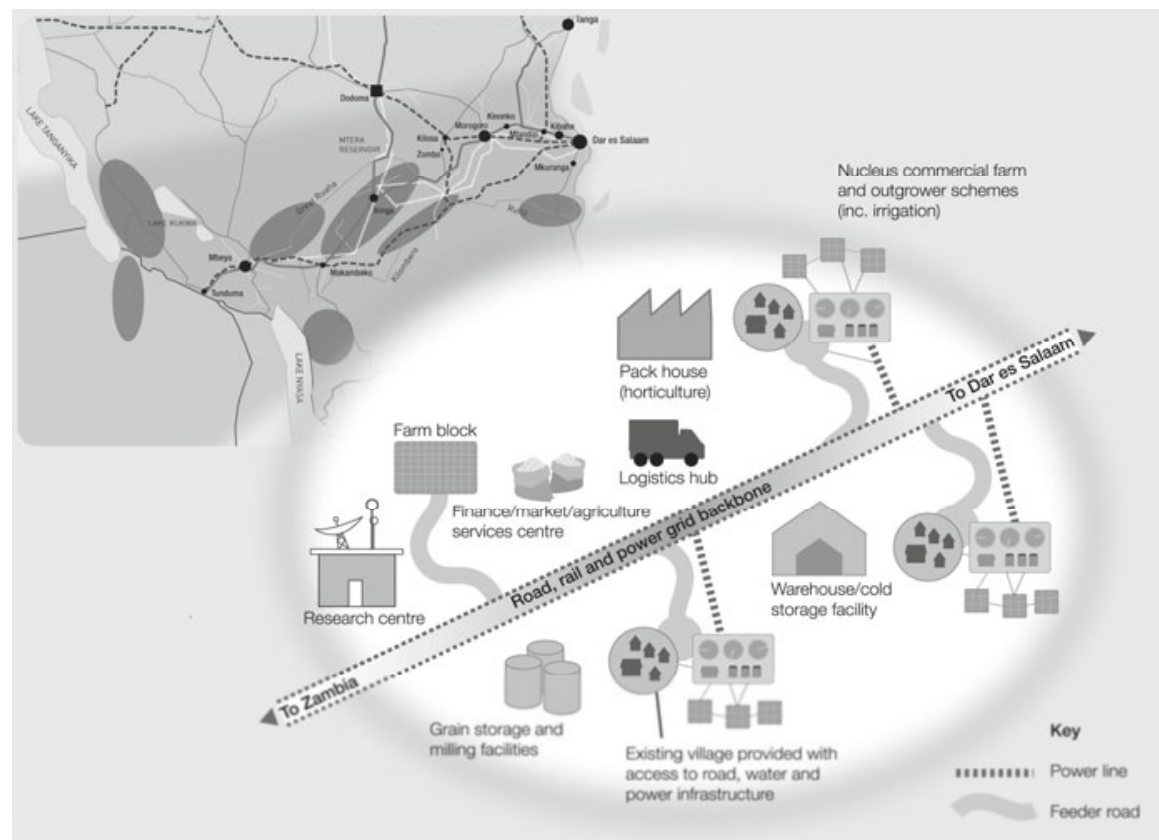

Fig. 2. SAGCOT - Infrastructure backbone

40 According to the ICA; www.icafrica.org.

41 CSIS, “Agricultural Productivity in Changing Rural Worlds", 2010. 
A critical part of modern infrastructure is not only market access, but market information. Most often cut off from the markets, African smallholders have been at a disadvantage when negotiating the terms of transactions. In recent years, price information - and financial services - are readily available through the extension of ICT, not least mobile phone services such as the M-pesa in Kenya. ${ }^{42}$ Through wireless digital technology farmers can also gather agricultural advice, and thus increase their yields.

At the African Green Revolution Forum in Accra in 2010, the president of IFAD, Kanayo F. Nwanze, put it succinctly: "Smallholder farmers need roads and financial services not handouts."

\section{Investment Opportunity}

Investments in infrastructure alone will not alone transform the agriculture sector and bring the necessary investment. There needs to be considerable attention in developing the kinds of integrated models that will take African agriculture to scale in a sustainable and responsible way. At the same time, any sustainable agricultural development strategy in Africa should also consider the nature of the continent and those who will live there in 20 years.

Transforming Africa's smallholder farmers into a viable economic force and allowing them to form part of market-orientated value chains is one of the biggest challenges we currently face. At the same time this challenge also represents a massive investment opportunity. The agricultural growth corridor model, is by no means the only model and for African agriculture to truly meet its potential a range of different models will need to be developed and compliment each other. It does set out just such a 20-year vision and the kind of integrated investment framework that would make such a transformation possible. By promoting an integrated approach to agricultural development that sees clusters of development being overlaid on to existing infrastructure backbone networks and using catalytic financing and patient capital to runlock greater amounts of local and international investment and to ensure this is done in a sustainable and responsible manner will be critical to ensuring Africa meets its own long term agricultural growth projections. As development within each cluster reaches a critical mass involving both smallholder and commercial farm development, it is expected that the corridor areas will experience a virtuous agricultural growth cycle with increased investment leading to more production, generating a supply chain response and economies of scale that further increase competitiveness, encourage more investment, and result in greater accelerated growth.

42 M-Pesa is a mobile-phone based money transfer service offered by Vodafone in Kenya, a concept initially conceived for allowing microfinance borrowers to receive and repay loans by mobile connectivity. 
Interviewed by the BBC during the AU summit in Addis Ababa in 2011, the World Bank Vice President for the Africa Region, Obiageli Ezekwesili, championed Africa, noting that the continent offers some of the highest returns on investments anywhere: "It would be a mistake for any corporation not to make Africa an investment destination." 43

\section{Grow Africa}

The agricultural growth corridor initiatives in have recently help inspire the establishment of Grow Africa, Both President Jakaya Kikwete of Tanzania and President Armando Emilio Gueguza of Mozambique, together with a range of other patrons representing leading bilateral and multilateral institutions, agreed to champion this wider platform. Grow Africa is a partnership between the African Union and NEPAD and the World Economic Forums New Vision for Agriculture which in line with national goals defined with the support of CAADP, sees an initial first wave of seven African countries ${ }^{44}$ develop a similar transformative public-private approaches to accelerating sustainable agricultural growth, though not necessarily in the form of a corridor.

\section{Conclusion}

A multitude of sources point to Africa's potential to scale up and improve its competitiveness in agricultural production. The lack of successes seems not to be connected to any one, singular cause, but it is rather a matter of unlocking a grid of entangled challenges to development. From a business point of view, the key is to invest in increased efficiency along the entire value chain. These investments need to be supported by an enabling environment supported by public policy priorities.

Several key views of the agricultural growth corridors address the challenges and may finally bring about lasting change. First, it is taking on a business and market view of agricultural development. A main focus is developing markets that create shared value across the sector, which is necessary to establish sustainable development. Second, a key determinant of success has been the active engagement of leadership in promoting the wider perspective necessary in ensuring the early success of such initiatives. Thirdly, the transformative and crosssector multilevel nature of the partnerships aim to harness the various partners' diverse capabilities to the best advantage. Finally, the innovative and multilayered approach to financing and managing risk is vital to attract private-sector investment. Risk is mitigated through weather-indexed insurance schemes, warehouse receipting, catalytic funding, and patient capital. The cluster approach or hub development add to all of these three perspectives, also adding a social dimension by providing

43 World Bank press release, 2 February 2011.

44 Burkina Faso, Ethiopia, Ghana Kenya, Mozambique, Rwanda, Tanzania. 
affordable services across the value chain to a wide number of both small holder and medium to large scale farmers alike.

On-the-ground results are only just beginning to appear. At the time of going to print, over 20 initial investments have been made using catalytic financing in Mozambique with similar catalytic investment facility forthcoming in Tanzania. Inspired by Mozambique and Tanzania, the Grow Africa partnership involving a further five countries in a transformative partnership approach to attracting investment into agriculture has also just begun to emerge. This all represents a small start to an ambitious process. Nevertheless, the level of interest raised by the corridor initiatives shows they strike a chord and if nurtured successfully over the medium to longer term could have a significant impact on rural development and food security in the region.

\section{References}

Africa Progress Panel (2010) Doing Good Business in Africa: How Business Can Support Development.

Annan, K. (2010) Africa's Green Revolution Forum: Initiating a Quantum Leap Forward. Accra.

AU/ECA (2009) Developing African Agriculture Through Regional Value Chains.

Center for Strategic \& International Studies (CSIS) (2010) Agricultural Productivity in Changing Rural Worlds.

Collier, P. (2010) The Plundered Planet.

IAASTD (2009) Agriculture at a Crossroads.

IFDC (2010) Press Release, 7 December 2010.

Swinnen, J., Maertens, M. (2013) Finance Through Food and Commodity Value Chains in a Globalized Economy. In this volume.

Technical Center for Agricultural and Rural Cooperation ACP-EU (2010) Report, 16 March 2010.

The infrastructure Consortium for Africa (ICA), www.icafrica.org.

World Bank (2011) Africa's Future and the World Bank's Support to It.

World Bank (2009) Africa's Infrastructure. A Time for Transformation.

World Bank (2010) Agriculture Action Plan 2010-2012.

World Bank (2010) Press Release, 2 February 2011.

World Bank (2011) World Development Report 2010: Reshaping Economic Geography. 